\title{
Photocatalytic degradation of reactive yellow 17 dye in aqueous solution in the presence of $\mathrm{TiO}_{2}$ with cement binder
}

\author{
B. Neppolian, ${ }^{1}$ S. R. Kanel, ${ }^{1}$ H. C. Choi, ${ }^{1, \dagger}$ M. V. Shankar, ${ }^{2}$ \\ Banunathi Arabindoo, ${ }^{2}$ and V. Murugesan ${ }^{2}$ \\ ${ }^{1}$ Department of Environmental Science and Engineering Kwangju Institute of Science and Technology (K-JIST), \\ Kwangju - 500 712, South Korea \\ ${ }^{2}$ Department of Chemistry, Anna University, Chennai - 600 025, India
}

\begin{abstract}
This study examined the photocatalytic degradation of common textile dye, reactive yellow 17 by photocatalysis over $\mathrm{TiO}_{2}$ (Degussa P25) photocatalyst coated on the glass plates (reactor) using cement as a binder. Sunlight was used as an energy source. The degradation efficiency was found to be the high at around neutral $\mathrm{pH}$ values. The influence of additives such as $\mathrm{H}_{2} \mathrm{O}_{2}, \mathrm{~K}_{2} \mathrm{~S}_{2} \mathrm{O}_{8}, \mathrm{Na}_{2} \mathrm{CO}_{3}$ or $\mathrm{NaCl}$, on the degradation efficiency of the dye in the presence of cement binder was systematically studied. Both $\mathrm{Na}_{2} \mathrm{CO}_{3}$ and $\mathrm{NaCl}$ were hindering the rate of photocatalytic degradation. Whereas, increase the initial concentrations of both $\mathrm{H}_{2} \mathrm{O}_{2}$ and $\mathrm{K}_{2} \mathrm{~S}_{2} \mathrm{O}_{8}$, increased the rate of degradation of the dye. UV-vis spectrophotometer and chemical oxidation demand were used to study decolourisation and degradation of dye, respectively. From this study, degradation of textile dye reactive yellow 17 with $\mathrm{TiO}_{2}$ photocatalyst coated on the glass plate using cement as a binder employing solar energy may emerge as a cost-effective method for textile dye wastewater of low concentration.
\end{abstract}

\section{INTRODUCTION}

The discharge of wastewater that contains high concentration of reactive dyes is a well-known problem associated with dye stuff activities. Some of these dyes have documented health hazards [1]. There are different physico-chemical and biological methods for the treatment of reactive dyes in wastewater. However, these processes have high operating cost and are of limited applicability. If not removed, would cause disturbance to the ecological system of the receiving waters [2-4]. Hence, the necessity of investigating new alternatives for the adequate treatment of the dye present in wastewater is inevitable.

Thus many processes have been proposed over the years and are currently employed to destroy toxic chemicals discharged along with textile wastewater. Photocatalytic detoxification (AOPs) has been focussed as an alternative method to clean up polluted water. This technique adopts the possibility of combining the heterogeneous catalysis with solar light to achieve mineralisation of toxic pollutants present in textile wastewater [5]. In the past few years many catalysts like $\mathrm{TiO}_{2}, \mathrm{ZnO}, \mathrm{WO}_{3}, \mathrm{SnO}_{2}, \mathrm{ZrO}_{2}, \mathrm{CeO}_{2}, \mathrm{CdS}$ and $\mathrm{ZnS}$ have been attempted for photocatalytic oxidation of water borne environmental contaminants $[1,6]$. In the present study, $\mathrm{TiO}_{2}$ assisted photocatalytic degradation of reactive yellow 17 dye coated on the glass plate (reactor) using cement as a binder is reported. The effects of the concentrations of $\mathrm{H}_{2} \mathrm{O}_{2}, \mathrm{~K}_{2} \mathrm{~S}_{2} \mathrm{O}_{8}, \mathrm{Na}_{2} \mathrm{CO}_{3}$

†E-mail: hcchoi@kjist.ac.kr and $\mathrm{NaCl}$ in the degradation of reactive yellow 17 dye were studied.

\section{EXPERIMENTAL}

2.1. Materials. The textile dye reactive yellow 17 $\left(\mathrm{C}_{21} \mathrm{H}_{20} \mathrm{O}_{10} \mathrm{~N}_{4} \mathrm{~S}_{3}\right)$ purchased from Vanavil (India) limited. The Titanium dioxide (Degussa P-25) obtained from Germany. The titania particles are a mixture of both anatase and rutile crystalline phase (mostly anatase) with an average particle size of $30 \mathrm{~nm}$ and surface area of $50 \mathrm{~m}^{2} / \mathrm{g}$ were used without any pretreatment. Portland cement is used in this study as a binder for the $\mathrm{TiO}_{2}$ on glass surface, mainly consists of $45 \%$ tricalcium silicate and 25\% dicalcium silicate and remaining is metal oxides and sulphates. Required concentration of solutions were prepared by dissolving the dye in distilled water $(17 \mathrm{M} \Omega)$.

2.2. Thin-film coated photocatalytic reactor. The photocatalyst powder $\left(\mathrm{TiO}_{2}\right)$ was thoroughly mixed with Portland cement in the ratio $1: 1$ by grinding. The mixture was then transformed into a semisolid mass with suitable addition of distilled water. The semisoild mass was applied physically to the inner surface of the Petri dish as a thin coating. It was then allowed to set for $2 \mathrm{~h}$. The dye solution was taken in the dish and exposed to direct sunlight. The Petri dish in this study is $15.5 \mathrm{~cm} \times 1.8 \mathrm{~cm}$ (diameter $\times$ height). The progress of photocatalytic degradation of the dye was monitored by withdrawing definite quantity of aliquots 
at regular intervals and measuring the absorbance in the UV-visible spectrophotometer for decolourisation and degradation using COD method.

2.3. Analysis. The decolorisation of reactive yellow 17 was measured with UV-vis spectrophotometer (Model Hitachi UV-2000, doble beam, Japan) at $596 \mathrm{~nm}$. The chemical oxygen demand (COD) was measured by the closed reflux method [7]. The dye solution with catalyst in the reactor were withdrawn at periodic intervals and analyzed after centrifugation for decolorization and degradation. $\mathrm{CO}_{2}$ was tested by bubbling through lime water, sulphate by turbidimetry and $\mathrm{NH}_{4}{ }^{+}$and $\mathrm{NO}_{3}{ }^{-}$ions by spectrophotometic method.

\section{RESULTS AND DISCUSSION}

Reactive Yellow 17 dye was degraded in the presence of $\mathrm{TiO}_{2}$ (coated on the glass plates using cement as a binder) by irradiation with solar light. A blank experiment in the absence of irradiation illustrated the rapid attainment of adsorption equilibrium of the dye on to $\mathrm{TiO}_{2}$. Another experiment in the absence of $\mathrm{TiO}_{2}$ with irradiation showed no significant degradation. This clearly indicates that this reaction follows photocatalytic degradation.

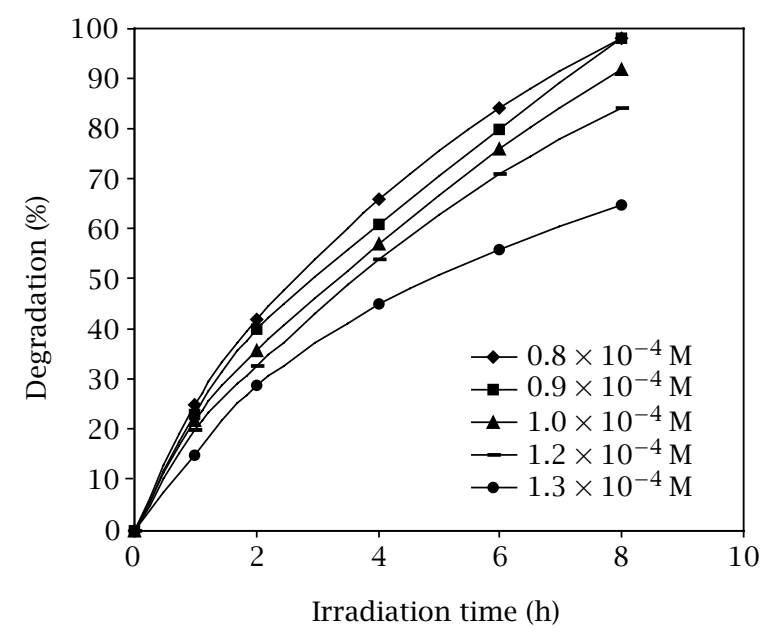

Figure 1. Influence of different initial concentrations of reactive yellow 17 dye $\left(\mathrm{TiO}_{2}\right.$ and Cement: $\left.200 \mathrm{mg}(1: 1)\right)$.

3.1. Influence of initial concentration of dye. Figure 1 illustrates the degradation of different initial concentration of the dye $\left(0.8-1.3 \times 10^{-4} \mathrm{M}\right)$ by photocatalysis in the presence of $\mathrm{TiO}_{2}$. It is found that $1.2 \times 10^{-4} \mathrm{M}$ dye degraded to $84 \%$ by photocatalysis in the presence of $200 \mathrm{mg}$ each of $\mathrm{TiO}_{2}$ and cement in 8 hours. So we fixed the initial concentration of dye as $1.2 \times 10^{-4} \mathrm{M}$. After fixing the initial concentration of dye, experiments were carried out by varying different concentrations of cement and $\mathrm{TiO}_{2}$.

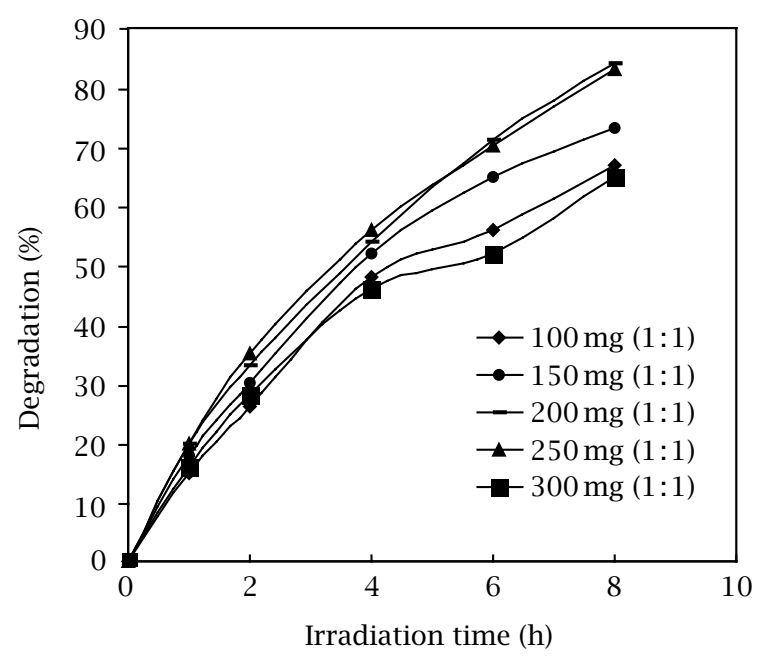

Figure 2. Influence of different amounts of $\mathrm{TiO}_{2}$ and cement $(1: 1)$ in the degradation of reactive yellow 17 dye $\left(1.2 \times 10^{-4} \mathrm{M}\right)$.

3.2. Influence of titanium dioxide catalyst and cement $(1: 1)$. The results of photodegradation of the dye $\left(1.2 \times 10^{-4} \mathrm{M}\right)$ over different amounts of $\mathrm{TiO}_{2}$ and cement $(100,150,200,250,300 \mathrm{mg}$, i.e. $1: 1$ ratio) are illustrated in Figure 2. With an increase of $\mathrm{TiO}_{2}$ dosages, the rate was enhanced due to the increase of active site for the production of $\mathrm{OH}$ radicals. The degradation reached maximum at an optimum concentration of $\mathrm{TiO}_{2}$ (200mg). Further increasing the dosage, degradation of dye decreased due to increase of turbidity, which reduces the light transmission through solution. While below this optimum level, it is assumed that the catalyst surface and adsorption of light by the catalyst are limited. Particle interaction becomes significant as the number of particles in solution increases. This reduces the site density for surface holes and electrons [8]. Similar result was observed by Reutergarth \& Langphasuk (1997), [1] during the degradation of reactive dye using $\mathrm{TiO}_{2}$.

3.3. Influence of $\mathrm{pH}$. The effect of another important parameter in photodegradation, $\mathrm{pH}$, experiment were conducted at different initial $\mathrm{pH}$ values varying from 5 to 12 and results are shown in Figure 3. The percent degradation of the dye was unchanged with increasing of $\mathrm{pH}$ up to 10 and further increasing of $\mathrm{pH}$, the degradation was decreased. The inhibitory effect seems to be more pronounced at alkaline range. At high $\mathrm{pH}$ values, the $\mathrm{OH}$ radical concentration is high and hence the chances of recombination is also high. The $\mathrm{pH}$ affects not only the surface properties of $\mathrm{TiO}_{2}$ but also the dissociation of the dye and formation of hydroxyl radicals. In the present case, it can be presumed that the main reaction is presented by the hydroxyl radical attack, which can be favored by the high concentration of the hydroxyl radicals at around neutral $\mathrm{pH}$ [9]. 


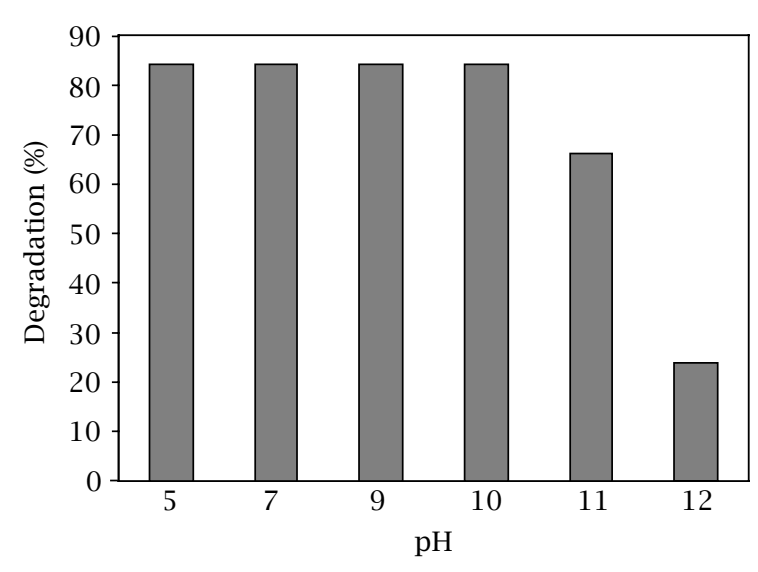

Figure 3. Influence of $\mathrm{pH}$ in the degradation of reactive yellow dye 17 dye $\left(1.2 \times 10^{-4} \mathrm{M}\right)$.

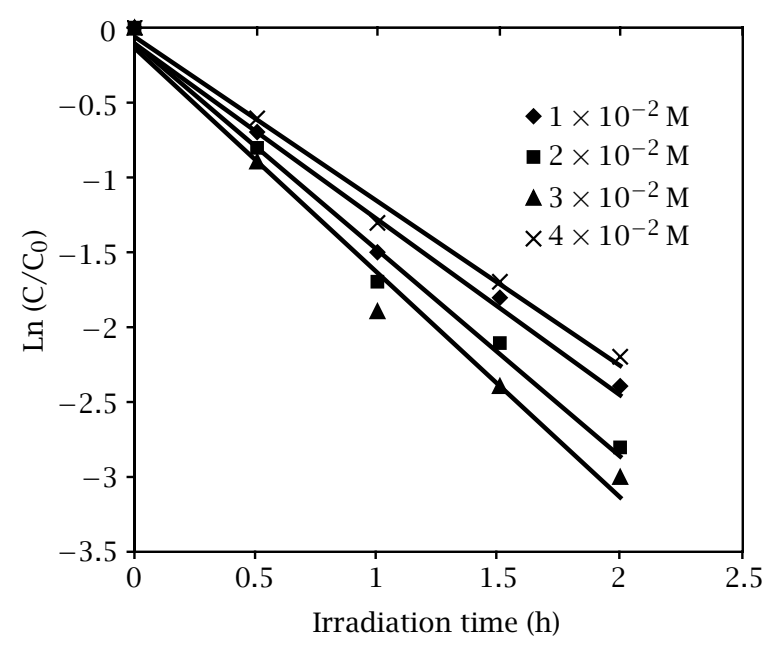

Figure 4. Kinetics of degradation of reactive yellow 17 dye $\left(1.2 \times 10^{-4} M\right)$ with different concentration of $\mathrm{H}_{2} \mathrm{O}_{2}$.

3.4. Influence of hydrogen peroxide. Figure 4 shows the influence of $\mathrm{H}_{2} \mathrm{O}_{2}$ dosage on the degradation efficiency of the dye in the light/ $\mathrm{TiO}_{2}$-cement system. Since reactive hydroxyl radicals are easily generated by the breakdown of hydrogen peroxide (eqs. (2)-(4)), the presence of hydrogen peroxide in the reaction mixture will play key role in the photocatalytic process [10]. The dye degradation with hydrogen peroxide indicated that the reaction followed the pseudo-first order kinetics with respect to different $\mathrm{H}_{2} \mathrm{O}_{2}$ concentrations. Rate constant of dye degradation was calculated from the slope of the plot of the dye concentration in logarithmic scale with time and listed in Table 1.

The increase of $\mathrm{H}_{2} \mathrm{O}_{2}$ concentration, resulted in a faster degradation of the dye was observed. This is due to photolysis of $\mathrm{H}_{2} \mathrm{O}_{2}$ to produce $\mathrm{OH}$ radical $\left(\mathrm{H}_{2} \mathrm{O}_{2}+\right.$ $h v \rightarrow 2 \mathrm{OH}^{\bullet}$ ) and $\mathrm{H}_{2} \mathrm{O}_{2}$ is suitable for trapping electrons [11] by preventing the recombination of $\mathrm{e}^{-}$and $\mathrm{h}^{+}$pairs, thus increasing the chance of the formation
Table 1. Rate constant of degradation of Reactive Yellow 17 dye.

\begin{tabular}{ccc}
\hline $\mathrm{H}_{2} \mathrm{O}_{2} \times 10^{-2} \mathrm{M}$ & Rate constant $(\mathrm{k} / \mathrm{sec}) \times 10^{-4}$ & $\mathrm{R}^{2}$ \\
\hline 1 & 3.508 & 0.98 \\
2 & 3.500 & 0.98 \\
3 & 4.161 & 0.97 \\
4 & 3.198 & 0.99 \\
\hline
\end{tabular}

of $\mathrm{OH}$ radical and $\mathrm{O}_{2}{ }^{-}$on the surface of the catalyst. The percent degradation has been found to be very high in the presence of hydrogen peroxide in comparison to the results in the absence of hydrogen peroxide. It was noted that $100 \%$ degradation was achieved with $4 \mathrm{~h}$ in the presence of hydrogen peroxide $\left(3 \times 10^{-3} \mathrm{M}\right)$ instead of $84 \%$ degradation in the absence of hydrogen peroxide in $8 \mathrm{~h}$. It has been widely reported that the addition of small amount of hydrogen peroxide greatly enhances the oxidation of organic pollutants mediated by $\mathrm{TiO}_{2}$ catalyst [10]. The enhanced photodegradation efficiency in the presence of hydrogen peroxide may be either directly via conduction band electrons or indirectly via superoxide radical anion which produces hydroxyl radicals [12]. The degradation of the dye increased rapidly up to $\mathrm{H}_{2} \mathrm{O}_{2}$ concentration of $3 \times 10^{-2} \mathrm{M}$. The further increase of $\mathrm{H}_{2} \mathrm{O}_{2}$ concentration $\left(4 \times 10^{-2} \mathrm{M}\right)$, considerably decreased the rate of the degradation of dye. This is due to quenching of $\mathrm{OH}$ radical by $\mathrm{H}_{2} \mathrm{O}_{2}$ (eq. (1)). Perhydroxide radical is significantly less reactive than $\mathrm{OH}$ radical with respect to organic oxidation [11], (eq. (1))

$$
\begin{aligned}
\mathrm{H}_{2} \mathrm{O}_{2}+\mathrm{OH}^{\bullet} & \longrightarrow \mathrm{HO}_{2}{ }^{\bullet}+\mathrm{H}_{2} \mathrm{O}, \\
\mathrm{H}_{2} \mathrm{O}_{2}+\mathrm{e}^{-} & \longrightarrow \cdot \mathrm{OH}+\mathrm{OH}^{-}, \\
\mathrm{H}_{2} \mathrm{O}_{2}+\mathrm{O}_{2}^{-} \cdot & \longrightarrow \cdot \mathrm{OH}+\mathrm{OH}^{-}+\mathrm{O}_{2}, \\
\mathrm{H}_{2} \mathrm{O}_{2} & \longrightarrow 2^{\bullet} \mathrm{OH}, \\
\mathrm{H}_{2} \mathrm{O}_{2} & \longrightarrow \mathrm{O}_{2}{ }^{2-}+2 \mathrm{H}^{+} .
\end{aligned}
$$

3.5. Influence of potassium persulphate. In this study, the effect of persulphate ion on the photocatalytic degradation of the dye was investigated (concentration of $\mathrm{K}_{2} \mathrm{~S}_{2} \mathrm{O}_{8}: 25$ to $200 \mathrm{mg} / 100 \mathrm{ml}$ dye solution, $4 \mathrm{~h}$ ). The data are presented in Figure 5. The percentage degradation of the dye increased with increasing amount of persulphate ion concentration and achieved $98 \%$ degradation within $4 \mathrm{~h}$ irradiation time with $200 \mathrm{mg}$ persulphate ion concentration instead of $84 \%$ degradation in the absence persulphate ion at $8 \mathrm{~h}$. It is a beneficial oxidising agent in photocatalytic detoxification because $\mathrm{SO}_{4}{ }^{-}$is formed from the oxidant by reaction (eqs. (6) and (7)) with the semiconductor generated electrons $\left(\mathrm{e}^{-} \mathrm{cb}\right)$

$$
\begin{aligned}
& \mathrm{S}_{2} \mathrm{O}_{8}{ }^{2-}+\mathrm{e}^{-} \text {aq } \longrightarrow \mathrm{SO}_{4}{ }^{-}+\mathrm{SO}_{4}{ }^{2-}, \\
& \mathrm{S}_{2} \mathrm{O}_{8}{ }^{2-}+\mathrm{e}^{-} \mathrm{cb} \longrightarrow \mathrm{SO}_{4}{ }^{-}+\mathrm{SO}_{4}{ }^{2-}
\end{aligned}
$$




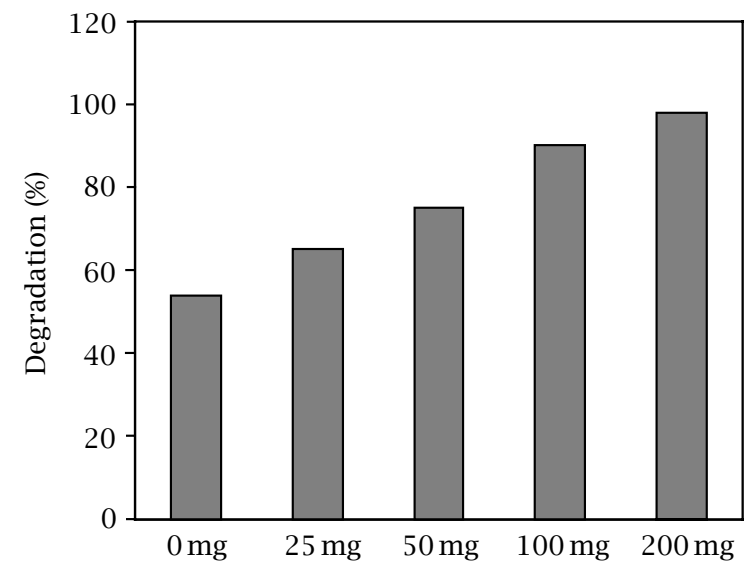

Concentration of persulphate ion $(100 \mathrm{~mL}$ of dye $/ 4 \mathrm{~h})$

Figure 5. Influence of $\mathrm{K}_{2} \mathrm{~S}_{2} \mathrm{O}_{8}$ in the degradation of reactive yellow dye $17\left(1.2 \times 10^{-4} \mathrm{M}\right)$.

The sulphate radical anion $\left(\mathrm{SO}_{4}^{-\bullet}\right)$ is a strong oxidant $\left(\mathrm{E}^{0}=2.6 \mathrm{eV}\right)$ and engages in the following three possible modes of reactions with organic compounds. (i) by abstracting a hydrogen atom from saturated carbon. (ii) by adding to unsaturated or aromatic carbon and (iii) by removing one electron from the carboxylate anion and from certain neutral molecules [13]. In addition, it can trap the photogenerated electrons and/or generated hydroxyl radical [13-15]

$$
\begin{aligned}
& \mathrm{SO}_{4}^{-\bullet}+\mathrm{e}^{-} \text {cb } \rightarrow \mathrm{SO}_{4}{ }^{2-} \\
& \mathrm{SO}_{4}{ }^{-\bullet}+\mathrm{H}_{2} \mathrm{O} \longrightarrow{ }^{\bullet} \mathrm{OH}+\mathrm{SO}_{4}{ }^{2-}+\mathrm{H}^{+}
\end{aligned}
$$

The formation of hydroxyl radical and sulphate radical anion (eqs. (10) and (11)) are powerful oxidants that can degrade the dye molecules at faster rate. The $\mathrm{SO}_{4}{ }^{-}$. has the unique nature of attacking the dye molecule at various positions and hence the fragmentation of the dye molecules is rapid [5]

$$
\begin{aligned}
& \mathrm{SO}_{4}{ }^{-\bullet}+\text { dye } \longrightarrow \mathrm{SO}_{4}{ }^{2-}+\text { dye }^{+\bullet} \text { (intermediate) } \\
& \mathrm{SO}_{4}{ }^{-\bullet}+\text { dye }^{+\bullet} \text { (intermediate) } \\
& \quad \longrightarrow \mathrm{SO}_{4}{ }^{2-}+\mathrm{CO}_{2}+\mathrm{HNO}_{3}+\text { other inorganics. }
\end{aligned}
$$

3.6. Influence of sodium carbonate. Sodium carbonate is the common auxiliary chemical employed in textile processing operations. Sodium carbonate is mainly used in the dyeing bath in order to adjust the $\mathrm{pH}$ of the bath as it plays an important role in the fixing of dye on the fabrics and in the fastness of color. Therefore the wastewater from the dyeing operation will contain considerable amount of carbonate ion. Hence it is important to study the influence of carbonate ion in the treatment efficiency. Experiments were performed with sodium carbonate, the percent degradation gradually decreased with increasing carbonate ion concentration as shown in Figure 6 [16]. The decrease in the

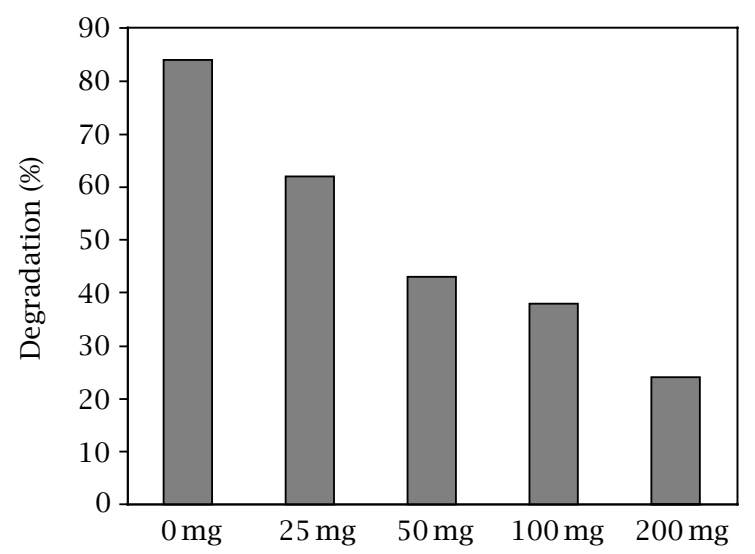

Concentration of Sodium carbonate ( $100 \mathrm{~mL}$ dye $/ 8 \mathrm{~h}$ )

Figure 6. Influence of $\mathrm{Na}_{2} \mathrm{CO}_{3}$ in the degradation of reactive yellow dye $17\left(1.2 \times 10^{-4} \mathrm{M}\right)$.

degradation of the dye in the presence of carbonate ions is due to the hydroxyl scavenging property of carbonate ions, which can be accounted from the following reaction (eqs. (12) and (13))

$$
\begin{gathered}
\cdot \mathrm{OH}+\mathrm{CO}_{3}^{2-} \longrightarrow \mathrm{OH}^{-}+\mathrm{CO}_{3}{ }^{\bullet-}, \\
\cdot \mathrm{OH}+\mathrm{HCO}_{3}{ }^{-} \longrightarrow \mathrm{H}_{2} \mathrm{O}+\mathrm{CO}_{3}{ }^{\bullet-} .
\end{gathered}
$$

This type of trend was also observed in the photocatalytic degradation of reactive dyes [17]. Behar et al., (1970) [18], reported the possibility of generating carbonate radicals $\left(\mathrm{CO}_{3}{ }^{\bullet-}\right)$ with the help of hydroxyl radicals. Thus the free hydroxyl radical which is a primary source (oxidant) for the photocatalytic degradation found to decrease gradually with increase in carbonate ions and ultimately significant decrease in the percent degradation of the dye [5].

3.7. Influence of sodium chloride. Sodium chloride usually comes out in the effluent along with sectional wastes in textile mills. Hence studies have been carried out with sodium chloride in the range 25$200 \mathrm{mg} / 100 \mathrm{~mL}$ dye solution.

The percent degradation of the dye decreased with increase of the amount of chloride ion. The results shown in the Figure 7 are in good agreement with those published by Abdullah et al., (1990) [19], who reported a strong inhibiting effect of chloride and phosphate ions when they studied the photocatalytic degradation of salicylic acid, aniline and ethanol. The decrease in the degradation of dye in the presence of chloride ion is due to the hole scavenging properties of chloride ion as shown in the following equations 14 and 15 [20]. This is a typical example for competitive inhibition. The reaction of dye molecules with the holes will have to compete with reaction

$$
\mathrm{TiO}_{2} \longrightarrow \mathrm{TiO}_{2}\left(\mathrm{~h}^{+}{ }_{\mathrm{vb}}, \mathrm{e}^{-} \mathrm{cb}\right),
$$




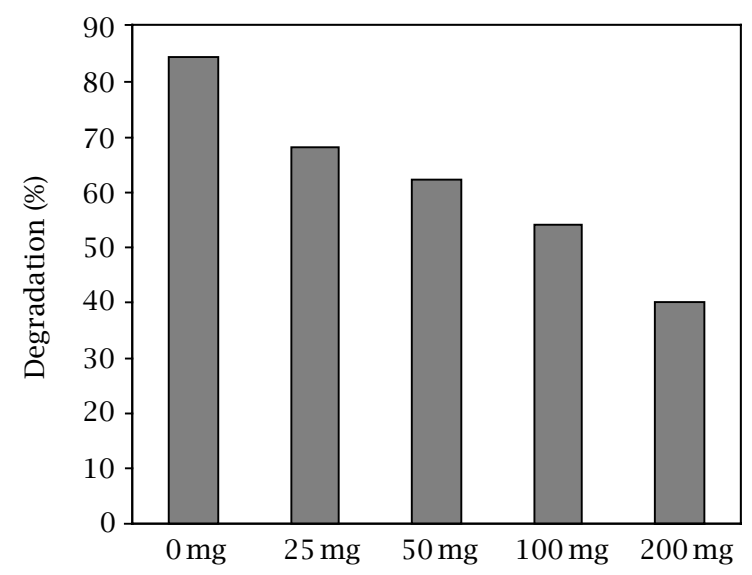

Concentration of Sodium chloride $(100 \mathrm{~mL}$ dye/8h)

Figure 7. Influence of $\mathrm{NaCl}$ in the degradation of reactive yellow dye $17\left(1.2 \times 10^{-4} \mathrm{M}\right)$.

$$
\begin{aligned}
& \mathrm{Cl}^{-}+\mathrm{h}^{+}{ }_{\mathrm{vb}} \rightarrow \mathrm{Cl}^{\bullet}, \\
& \mathrm{Cl}^{\bullet}+\mathrm{Cl}^{-} \longrightarrow \mathrm{Cl}_{2}^{\bullet} .
\end{aligned}
$$

While chlorine atoms are forming slowly, they are instantaneously converted into chloride radical anion (eq. (16)). Alternatively, surface sites normally available at the $\mathrm{TiO}_{2}$ /dye solution interface for the adsorption and electron transfer from the dye can be blocked by anions such as chloride and phosphate which are not readily oxidisable but yet very effective inhibitors for the detoxification process. However reversible by washing the catalyst with pure water to fully restore its photocatalytic activity when chloride ions were present in the wastewater.

\section{CONCLUSION}

From the foregoing discussions, it is seen that $\mathrm{TiO}_{2}$ catalyzed (with cement binder) photodegradation using solar irradiation is a suitable technique for removal of colored wastewater from textile industries. The oxidizing agents such as hydrogen peroxide and persulphate ion have major role in the degradation efficiency of the reactive yellow 17 dye. The additives such as sodium carbonate and sodium chloride are hindering the rate of photocatalytic degradation but it can be removed by diluting the dye solution to appropriate concentration and washing the catalyst. Hence the photodegradation of textile dyes employing solar energy may emerge as a viable method because of its eco-friendliness and cost effective.

\section{REFERENCES}

[1] L. B. Reutergardh and M. Iangphasuk, Chemosphere 35(3) (1997), 585.

[2] B. Neppolian, S. Sakthivel, Banumathi Arabindoo, M. Palanicahmy, and V. Murugesan, Stud. Surf. Sci. Catal. 113 (1998), 329.

[3] Wang Yizhong, Wat. Res. 34(3) (2000), 990.

[4] S. K. Chaudhari and Sur Babita, J. of Environmental Engineering 126(7) (2000), 583.

[5] B. Neppolian, H. C. Choi, S. Sakthivel, A. Banunathi, and V. Murugesan, Chemosphere 46 (2002), 1173.

[6] D. F. Ollis and H. Al-Ekabi, Photocatalytic purification and treatment of water and air, Elsevier, Amsterdam, III, 1993.

[7] APHA, Standard methods for the examination of water and wastewater, American Water Works Association, New York, 1989.

[8] J. Lea and A. A. Adesina, J. Chem. Sco. Faraday Trans. 80 (2001), 457.

[9] B. Neppolian, H. C. Choi, S. Sakthivel, B. Arabindoo, and V. Murugesan, J. Hazard. Mat. B 89 (2002), 303.

[10] J. Kiwi, C. Pulgarin, P. Peringer, and M. Graztel, New J. Chem. 17 (1993), 487.

[11] Y. Wang and C. S. Hong, Wat. Res. 33(9) (1999), 2031.

[12] P. Pichat, C. Guillard, L. Amalric, A. C. Renard, and O. Plaidy, Solar energy materials and solar cells 38 (1995), 391.

[13] C. Nasr, K. Vinodgopal, S. Kotchandani, A. K. Chattopadhyay, and P. K. Kamat, Chem. Intermed. 23 (1997), 219.

[14] E. Pelizzetti, V. Carlin, C. Minero, and M. Gratzel, New. J. Chem. 15 (1991), 351.

[15] C. Minero, E. Pelizzetti, S. Malato, and J. Blanco, Chemosphere 26 (1993), 2103.

[16] G. V. Buxton, C. C. Greenstock, W. P. Helman, and A. B. Ross, J. Phy. Chem. 17 (1988), 513.

[17] D. Nansheng, F. Tao, and T. Shizhong, Chemosphere 33 (1996), 547.

[18] D. Behar, G. Czapki, and I. Duchovny, J. Phy. Chem. 74(10) (1970), 2206.

[19] M. Abdullah, G. K. C. Low, and R. W. Matthws, J. Phys. Chem. 94 (1990), 6820.

[20] D. Bockelmann, M. Linder, and D. Bahnemann, From nanosized particles to commercial products, the search for novel photocatalysis (E. Pelizzetti, Ed.), Fine particles science and technology, Kulwer Academic Publishers, Netherlands, 1996, pp. 675689. 


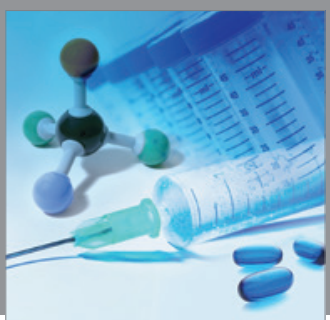

International Journal of

Medicinal Chemistry

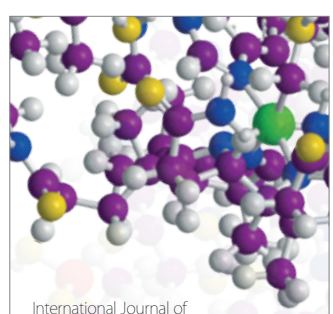

Carbohydrate Chemistry

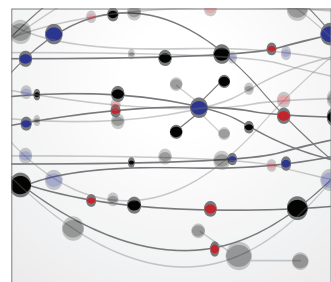

The Scientific World Journal
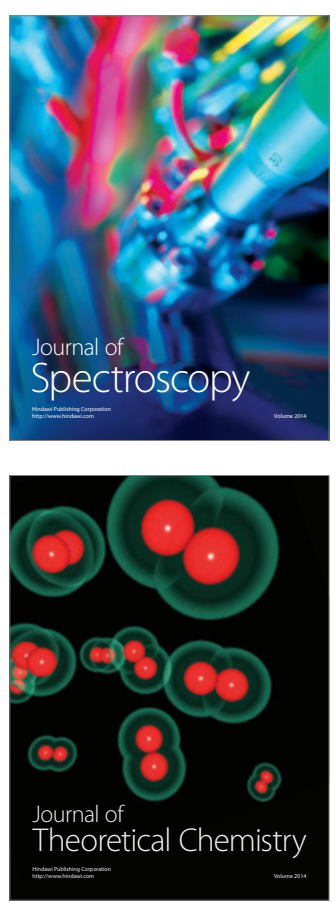
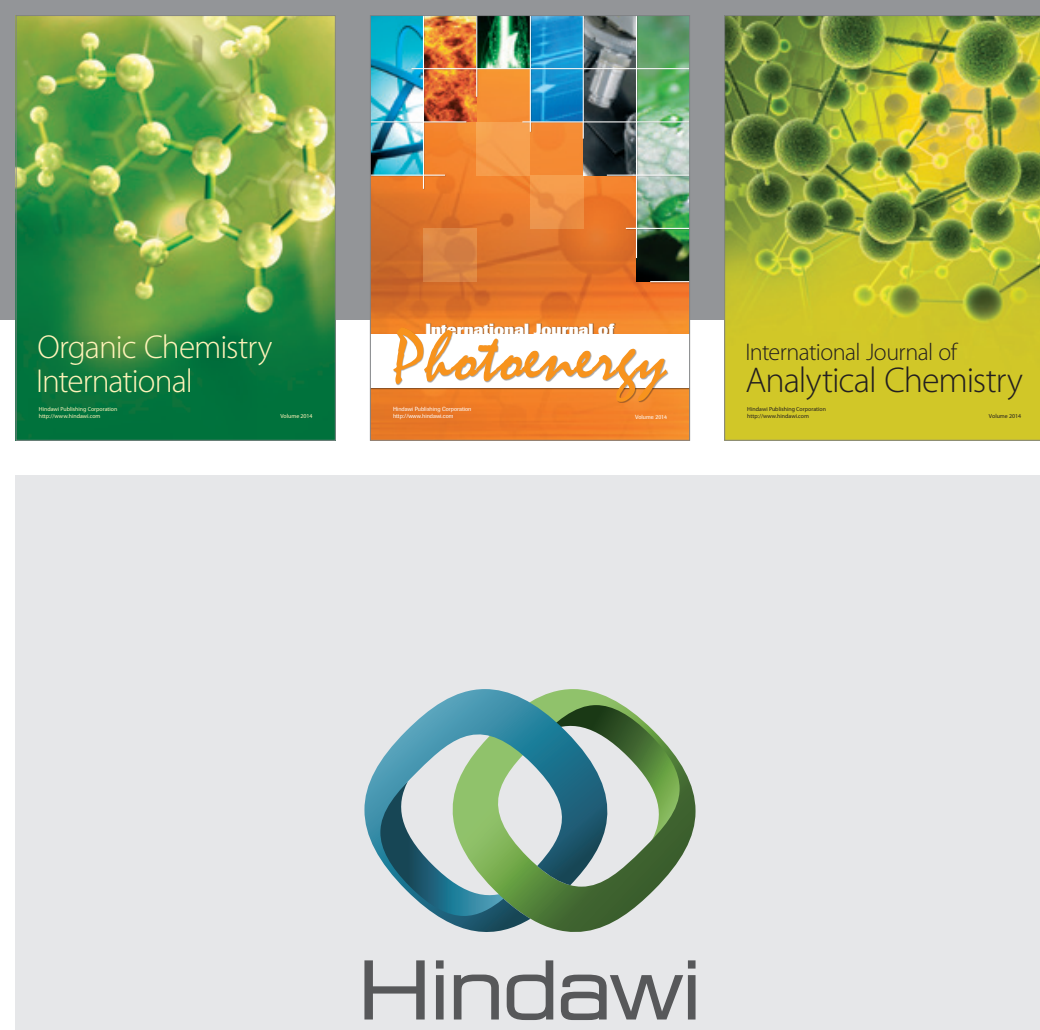

Submit your manuscripts at

http://www.hindawi.com
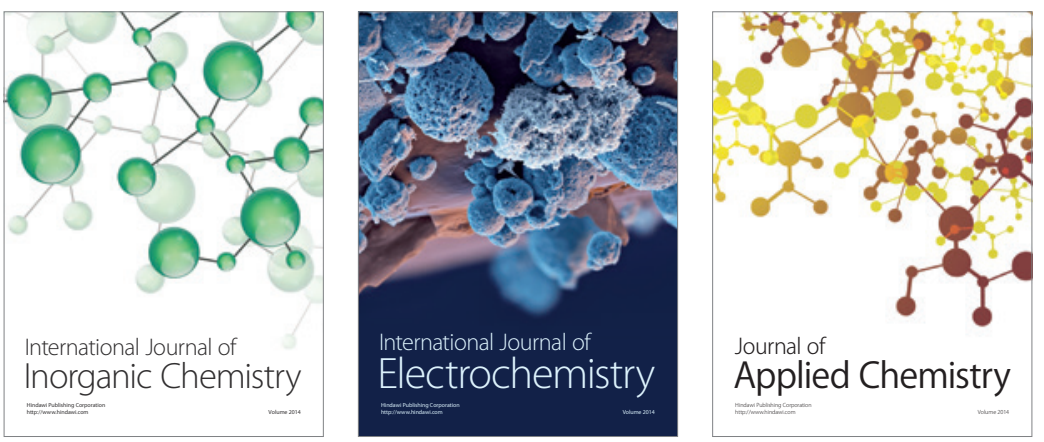

Journal of

Applied Chemistry
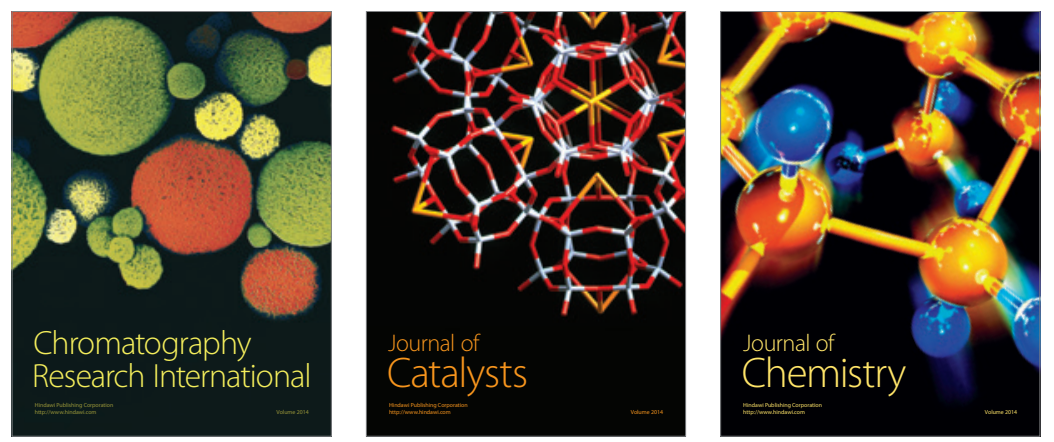
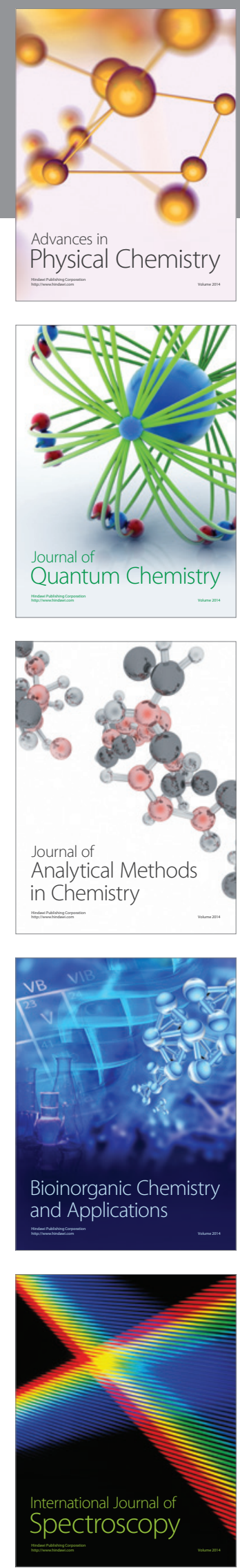